\title{
Evaluation of the socioeconomic and environmental sustainability of banking institutions in Brazil using the Analytic Hierarchy Process with ratings approach
}

\author{
Avaliação da sustentabilidade socioeconômica e ambiental de \\ instituições bancárias no Brasil utilizando o Método Analytic Hierarchy \\ Process com ratings
}

\author{
Igor Laguna Vieira ${ }^{1}$ (i), Luis Alberto Duncan Rangel ${ }^{2}$ (1), Elmo Rodrigues da Silva ${ }^{1}$ (), \\ Luiz Carlos De Martini Junior ${ }^{1}$ (1) \\ 1Universidade do Estado do Rio de Janeiro - UERJ, Rio de Janeiro, RJ, Brasil. E-mail: igor_laguna@hotmail.com; \\ elmorodrigues@yahoo.com.br; demartini@demartiniambiental.com.br \\ 2Universidade Federal Fluminense - UFF, Volta Redonda, RJ, Brasil. E-mail: duncan@metal.eeimvr.uff.br
}

\author{
How to cite: Vieira, I. L., L. A. D. Rangel, Elmo Rodrigues da Silva' \& Luiz Carlos De Martini Junior (2021). \\ Evaluation of the socioeconomic and environmental sustainability of banking institutions in Brazil using the \\ Analytic Hierarchy Process with ratings approach. Gestão \& Produção, v28(3), e5407. \\ https://doi.org/101590/1806-9649-2021v28e5407
}

\begin{abstract}
Large banking institutions play an important role in sustainable development, especially owing to their size and capillarity. Therefore, the objective of this study is to compare sustainability indicators (economic, environmental, and social) published in the reports of some of these institutions that operate in the Brazilian market. The four banks selected for this study were the ones that published their sustainability reports in the 2017 Global Reporting Initiative standard, and that comprised the portfolio of the Corporate Sustainability Index, promoted by "Brasil, Bolsa e Balcão," in 2018. These banks were Banco do Brasil, Bradesco, Itaú, and Santander. The analytic hierarchy process (AHP) with the use of ratings was used to carry out the research. After elaborating on the hierarchical structure of the problem, specialists, who were researchers in the field of sustainability, were required to weigh the degree of relevance of each of the indicators analyzed in this study. A ranking of the selected banks was then obtained in relation to their sustainability performances, which was based on the weights given to each indicator and the data available in the sustainability reports of each institution investigated. The banks were ranked in the following order: Itaú, Santander, Bradesco, and Banco do Brasil. The results of this study showed that there is room for evolution in relation to sustainability, mainly in the social department, in the banking sector. The AHP method with the use of ratings proved to be efficient, especially because it allowed for the weighing of the evaluation criteria and sub-criteria; this proved the usefulness of the method in comparing companies with regard to their sustainability performance.
\end{abstract}

Keywords: Sustainable development; AHP; Banking institutions; Global Reporting Initiative; Sustainability indicators; GRI reports.

Resumo: Considerando o importante papel desempenhado pelas grandes instituições bancárias em prol do desenvolvimento sustentável, especialmente devido ao porte e à capilaridade dessas organizações, objetiva-se neste artigo comparar indicadores de sustentabilidade (econômicos, 
ambientais e sociais) divulgados em relatórios de algumas dessas instituições que atuam no mercado brasileiro. Os quatro bancos selecionados para esta pesquisa são aqueles que publicaram os seus relatórios de sustentabilidade no padrão da Global Reporting Initiative para 2017 e que compunham a carteira do Índice de Sustentabilidade Empresarial, promovido pela "Brasil, Bolsa e Balcão”, em 2018. São eles: Banco do Brasil; Bradesco; Itaú; e Santander. Para a consecução da pesquisa foi utilizado o método Analytic Hierarchy Process (AHP) com o uso de ratings. Após a elaboração da estrutura hierárquica do problema, foi requerido que especialistas, pesquisadores da área de sustentabilidade, ponderassem o grau de relevância dos indicadores analisados nesta pesquisa. Construiu-se então um ranking dos bancos selecionados em relação ao desempenho de sustentabilidade, a partir dos pesos conferidos a cada indicador e dos dados disponíveis nos relatórios de sustentabilidade de cada instituição investigada. A ordem obtida no ranking foi a seguinte: Itaú; Santander; Bradesco; e Banco do Brasil. Conclui-se que os dados apontados neste trabalho mostram que há, no setor bancário, espaço para evolução em relação à sustentabilidade, principalmente na questão social. O método AHP com ratings se mostrou eficiente, especialmente por possibilitar ponderações dos critérios e subcritérios de avaliação, o que comprova sua utilidade na comparação de empresas no que concerne aos seus desempenhos de sustentabilidade.

Palavras-Chave: Desenvolvimento sustentável; AHP; Instituições bancárias; Global Reporting Initiative; Indicadores de sustentabilidade; Relatórios GRI.

\section{Introduction}

The concept of sustainable development emerged in the midst of environmental discussions, especially during the 1970 s and 1980s. The most widespread definition of the term is that derived from the report entitled "Our Common Future," also known as the "Brundtland Report," which was prepared in 1987; in this report, sustainable development is defined as the form of development that meets the need of the current generation without compromising those of future generations (WCED, 1987).

Another important concept, coined by Elkington (1997), is the so-called triple bottom line (people, planet, profit). In this approach, the term development encompasses economic growth as well as social improvements and environmental preservation, in an effort to guarantee the well-being of the population in the long term.

More recently, through the so-called 2030 Agenda for Sustainable Development, the United Nations (UN) renewed this call for attention to sustainability issues (Borgert et al., 2018). This Agenda is a universal action plan with three dimensions (social, economic, and environmental) and 17 Sustainable Development Goals (SDGs), which are expected to be achieved by 2030 . Some of these goals are issues such as achieving gender equality, ensuring the sustainable management of water and energy, and promoting sustained and inclusive economic growth (UN, 2015).

In this sense, business practices aimed at sustainable development have multiplied in recent years. Owing to the relevance of the theme, several studies have sought to shed light on the issue of sustainability in organizations with various end activities, such as those in the water and sanitation (Di Agustini \& Giannetti, 2018), textile (Amaral et al., 2018), furniture (Mello \& Mello, 2017), dairy (Santos et al., 2017), energy (Jugend \& Figueiredo, 2017), and agriculture (Sellitto \& Hermann, 2016) sectors.

Most of the studies on the topic of sustainability have focused on extractive and manufacturing organizations, possibly due to their high potential to generate environmental impacts. However, it is also important to investigate other sectors such as banking, as this sector employs a significant number of workers, and banking institutions are present in most Brazilian municipalities. According to data from the 2018 financial year, the five largest banking institutions in Brazil alone employed more than 400,000 
people (DIEESE, 2019). In the same year, approximately $93 \%$ of over than 5,000 Brazilian municipalities had some type of banking establishment (BCB, 2020).

By employing a large number of people throughout the country, banking institutions can generate a large positive social impact through policies that promote inclusion, such as encouraging gender and ethnic diversity in their staff. The importance of ensuring that all employees have an equal chance of professional growth is also emphasized.

The disclosure of sustainability reports by banks, with a greater emphasis on the Global Reporting Initiative (GRI) standard, are also worthy of attention. When an institution publicly assumes responsibility for the economic, environmental, and social impacts of its activities, it can encourage the incorporation of these issues by its stakeholders.

Thus, the objective of this study is to compare the socioeconomic and environmental sustainability of four banking institutions operating in the Brazilian market using the indicators described in their GRI reports in 2017. It is worth mentioning that banking institutions play an important role in promoting sustainable development, whether through internal actions or through granting credit to sustainable projects. However, this study focused on internal issues, such as water and energy consumption within the organization. Actions aimed to reduce such consumption, in addition to mitigating the environmental impact caused by banks, can bring economic benefits to these organizations, such as decreasing the amounts of money paid to concessionaires.

To achieve the research objective, we employed the Analytic Hierarchy Process (AHP) method, developed by Saaty (1980), with the use of ratings (Saaty, 2006). According to Saaty (1980), AHP is a tool for multicriteria decision support based on three principles: the structuring of a hierarchy, the stipulation of priorities, and the logical congruence of priorities. This tool is frequently addressed in the literature, which reinforces its application in multiple fields of study (Mello et al., 2017; Paoli \& Moraes, 2011; Ribeiro \& Alves, 2017; Rosa et al., 2015).

This paper is divided into six sections, starting with this introduction. Section 2 presents the theoretical framework of the study. Section 3 presents the methodology applied to achieve the proposed objective. In the following sections, we present and discuss the results of this study. Finally, the conclusions of the authors are presented in the sixth section.

\section{Theoretical framework}

\subsection{Multicriteria Decision Support}

The first Multicriteria Decision Support (MDS) methods emerged in the 1970s, with the aim of assisting decision makers in specific situations in which several objectives should be achieved simultaneously. These methods have both scientific and subjective characters, as they add the characteristics considered relevant, even qualitative ones. It is important to stress that such methods do not aim to present decision makers with an optimal solution to the problem, but rather to support the decision-making process (Gomes et al., 2004).

In the field of MDS, the American and French schools stand out. American school methods consider that when it comes to decision-making problems there is a real value function that aggregates the global values of the alternatives, according to the criteria defined by the decision makers. Thus, this theory assumes that the decision maker can identify several discrete alternatives for evaluation and is able to structure the evaluation criteria for these alternatives hierarchically. In contrast, French school methods suggest more malleable models, which do not necessarily impose a hierarchical relationship of the criteria on the decision maker, even though there is no impediment to the establishment of such a structure (Rosa et al., 2015). 
Examples of American school methods include the AHP (Saaty, 1980) and its variations, the Multiple Attribute Utility Theory (Maut) (Keeney \& Raiffa, 1976), MacBeth (Bana e Costa \& Vansnick, 1995), and the UTA-CR (Gomes \& Rangel, 2009a). The French school methods include the Elimination et Choix Traduisant la Réalité (Electre) method (Roy, 1968) and the Preference Ranking Organization Method for Enrichment Evaluations (Prométhée) (Brans et al., 1986). There are also hybrid methods, such as the Interactive and Multicriteria Decision Making (Todim) method (Gomes \& Lima, 1992a, b; Gomes \& Rangel, 2009b). The AHP method used in this work is possibly the most frequently used in the world when it comes to MDS (Rosa et al., 2015).

\subsubsection{The AHP method}

The AHP method, developed by Saaty (1980), allows decision-making problems to be modeled hierarchically. Based on a general objective, several evaluation criteria and sub-criteria are decomposed at different levels; this process facilitates the treatment and understanding of the problem. After building the hierarchy, the next step is to assign weights to each of these criteria and sub-criteria by means of a pairwise comparison, numerically. Finally, the alternatives are evaluated based on the last level of criteria or sub-criteria. The AHP allows decision makers to evaluate alternatives based on quantitative and qualitative criteria. It is a compensatory additive method, which means that, e.g., the low performance of one criterion can be compensated by the high performance of another.

To evaluate the relative importance of two criteria or sub-criteria, we used Saaty's fundamental scale (Saaty, 1980), as shown in Table 1.

Table 1. Fundamental Saaty Scale.

\begin{tabular}{ccc}
\hline 1 & Equal Importance & Two activities contribute equally to the objective. \\
\hline 3 & Moderate importance & Experience and judgement slightly favour one activity \\
over another.
\end{tabular}

Source: Saaty (1980).

The mathematical equations of the method have not been presented herein as they are easily accessible in the literature (see Ribeiro \& Alves, 2017). One of the limitations of the method is the subjective nature of the judgments in the comparison matrix, as these can vary depending on who is calculating the weights (Aharonovitz \& Vieira, 2014).

\subsubsection{AHP with ratings}

In the AHP approach with the use of ratings, which is also known as absolute measurement, the pairwise comparisons of criteria and sub-criteria occur as in the classical approach, but the alternatives receive values associated with a defined category, based on intensity levels (Saaty, 2006). 
One of the main advantages of this approach for Saaty (2008) is that it reduces the number of necessary pairwise comparisons, which is especially useful when there are many alternatives or when new alternatives need to be added after weights to the criteria and sub-criteria have been assigned. In addition, there is no order inversion when new alternatives are included.

Rahman et al. (2019) used AHP with ratings to propose a system of business excellence aimed at the Bangladesh hotel industry. In another example of the application of this approach, Petrillo et al. (2018) developed a carpooling system platform model based on different criteria.

\subsection{Global reporting initiative}

The GRI guidelines are currently the most widespread and used globally for the production of sustainability reports (Masud et al., 2018; Ryszawska \& Zabawa, 2018). Created in 1997 in Amsterdam (Netherlands), the GRI is a nonprofit organization, which is the result of a joint effort by the Coalition for Environmentally Responsible Economies (CERES) and the United Nations Environmental Program (UNEP), which aims to help governments and organizations understand business impacts on sustainable development (Campos et al., 2013).

The first version of the GRI guidelines for sustainability reporting was published in 2000 . Since then, these guidelines have been reviewed regularly, with the fourth and penultimate version, known as GRI G4, having been published in 2013 (Borges et al., 2018).

In October 2016, the GRI launched the GRI Standards. Developed by the Global Sustainability Standards Board (GSSB), this new GRI model allows organizations to disclose publicly their economic, environmental, and social impacts through indicators. The GRI Standards include the main concepts of the GRI G4 guidelines, improved for a more flexible structure, clearer requirements, and simpler language (GRI, 2020a).

The GRI advised organizations to adopt the new standard in their sustainability reports as early as 2016. After July 2018 , reports and other materials that refer to the GRI must adopt the new structure. Therefore, since then, the GRI G4 guidelines can no longer be used (GRI, 2018).

Sustainability reports, published according to the GRI guidelines, are the focus of several national and international publications (Campos et al., 2013; Fuente et al., 2017; Sucena \& Marinho, 2019). Several authors have pointed out positive points in the GRI reports, such as the model's popularity and credibility (Danoucaras et al., 2014; Scholl et al., 2015; Spuerk et al., 2017).

Although published studies recognize the importance of these reports, there are also criticisms of the model. Brooks \& Oikonomou (2018) warn that companies can use such reports as mere marketing instruments, even practicing so-called greenwashing, by highlighting the aspects in which they perform well, while suppressing the negative indicators, with the objective of showing a socio-environmentally responsible image, which is not always true.

Some authors point out that there is a lack of standardization in the way reports are published, which makes it difficult to compare organizations even within the same sector (Etzion et al., 2017; Ferreira-Quilice \& Caldana, 2015; Liubachyna et al., 2017; Siew, 2015).

According to the GRI database, since these guidelines emerged, 1,661 financial institutions around the world have released their reports following the format suggested by the organization. In Brazil, the number of these institutions is 50 (GRI, 2020b).

\subsection{Socioeconomic and environmental sustainability in banking institutions}

The increase in socio-environmental demands has led institutions, including banking ones, to strive to tie their brand to the concept of sustainability. The website of the Brazilian Federation 
of Banks (FEBRABAN) has a section dedicated exclusively to the theme, which includes actions that encourage the promotion of sustainable development in the banking sector. A representative example is the FEBRABAN Program for Valuing Diversity, which aims to promote equity and equal opportunities in the work environment for all bank employees (FEBRABAN, 2020).

Still in the wake of sustainability, the Central Bank of Brazil (BCB) published Resolution 4,327 (BCB, 2014), in 2014. The aforementioned standard provides that all financial institutions operating in Brazil must establish socio-environmental responsibility policies. According to Olher et al. (2018), such a resolution can contribute to financial institutions rethinking their processes and redefining their business strategies according to the risks involved in decision-making.

Several studies have investigated the issue of socioeconomic and environmental sustainability in banking institutions. Almeida et al. (2017) analyzed GRI reports (base year 2012) from four financial institutions operating in Brazil. The authors noted that there is no standardization in the way information is disseminated, which makes it difficult to establish comparisons among different banks, and even among the different years of the same bank. Another finding of the aforementioned study was that some information was unclear, which can impair readers' understanding.

Silva et al. (2019) also noted differences in the way banks disclose their information regarding sustainability after analyzing the GRI reports (base year 2017) of two Brazilian banks. In fact, as discussed in the previous section, several authors have already pointed out this fact; the lack of standardization in the GRI reports makes it difficult to establish comparisons, while this problem is not unique to the banking sector (Etzion et al., 2017; Ferreira-Quilice \& Caldana, 2015; Liubachyna et al., 2017; Siew, 2015).

The GRI reports of two Brazilian banks for the years 2015 and 2016 were examined by Olher et al. (2018). The authors found that the banks reported some corporate social responsibility practices, with an emphasis on philanthropic contributions. However, the authors characterized the approach to these practices as predominantly strategic. It follows that one should be cautious when it comes to greenwashing and verify that the sustainability reports of these companies are not merely marketing pieces (Brooks \& Oikonomou, 2018).

Rebelato et al. (2015) compared the environmental performance of the five main banks operating in Brazil, through examining their GRI reports that spanned the 2009-2012 period. In this study, economic and social aspects were not analyzed. The AHP method was used to weigh the environmental indicators. The authors ranked the banks in the following order: Bradesco, Itaú, Banco do Brasil, Santander, and Caixa Econômica Federal.

In the international literature, Avrampou et al. (2019) proposed and employed a method to assess the structure of the GRI indicators in order to compare the non-financial performance of European banks in terms of their contribution to the Agenda 2030 SDGs. The results of the study highlight a very limited overall performance regarding the organizational contribution to the SDGs, with heterogeneous disclosures from the studied banks.

\section{METHODOLOGY}

The research employed in the present study is characterized as descriptive regarding its objectives, and as documentary regarding the data collection procedures followed (Gil, 2017).

The methodology employed in this research was based on the AHP multicriteria method, using the ratings approach. This method was chosen because it offers a logical and representative way of structuring the problem in question by comparing factors in order to establish priorities. Additionally, this is a compensatory and well-established additive method, whether used in academia or in the corporate world. The method also 
allows for the ordering of alternatives. The ratings approach was used to reduce the number of necessary peer-to-peer comparisons.

\subsection{Selection of banking institutions}

In this study, we compared the sustainable performance of selected banking institutions operating in Brazil. The selected banks included those that published their sustainability reports in the GRI standard for 2017 and that comprised the 2018 portfolio of the Corporate Sustainability Index (ISE), promoted by "Brasil, Bolsa e Balcão"' (B3), which brought together companies with better corporate sustainability performance (B3, 2021). Table 2 shows the four selected banks.

Table 2. The banking institutions included in this study.

\begin{tabular}{|c|c|}
\hline Company name & Website \\
\hline Banco do Brasil & http://www.bb.com.br \\
\hline Bradesco & http://www.bradesco.com.br \\
\hline Itaú & http://www.itau.com.br \\
\hline Santander & http://www.santander.com.br \\
\hline
\end{tabular}

\subsection{Indicator selection}

In order to compare the sustainable performance of the selected banks, we obtained data from the GRI reports for 2017 that were published on their websites (version "GRI Standards"). Only quantitative indicators were considered, and an electronic spreadsheet was built based on the data obtained.

For comparison purposes, only the common indicators of the reports analyzed were selected. Thus, six indicators were selected, representing the three sustainability dimensions (economic, environmental, and social). The indicators are shown in Table 3.

Table 3. Selected Global Reporting Initiative (GRI) indicators.

\begin{tabular}{|c|c|c|c|}
\hline Indicator & Description & Analyzed Data & Dimension \\
\hline $201-1$ & $\begin{array}{l}\text { Direct economic value generated } \\
\text { and distributed }\end{array}$ & Net Income 2017/Net Income 2016 & \multirow[b]{2}{*}{ Economic } \\
\hline $205-2$ & $\begin{array}{l}\text { Communication and training about } \\
\text { anti-corruption policies and } \\
\text { procedures }\end{array}$ & $\begin{array}{l}\text { Number of employees trained in } \\
\text { fighting corruption/Number of } \\
\text { employees }\end{array}$ & \\
\hline $302-1$ & $\begin{array}{l}\text { Energy consumption within the } \\
\text { organization }\end{array}$ & $\begin{array}{l}\text { Energy consumption/Number of } \\
\text { employees }\end{array}$ & \multirow{2}{*}{ Environmental } \\
\hline $303-1$ & Water withdrawal by source & $\begin{array}{l}\text { Water consumption/Number of } \\
\text { employees }\end{array}$ & \\
\hline $401-1$ & $\begin{array}{c}\text { New employee hires and employee } \\
\text { turnover }\end{array}$ & Layoffs/Admissions & \multirow{3}{*}{ Social } \\
\hline \multirow[b]{2}{*}{$405-1$} & & $\begin{array}{l}\text { Number of women in governance } \\
\text { Bodies/Number of employees in } \\
\text { governance bodies (405-1a) }\end{array}$ & \\
\hline & $\begin{array}{l}\text { Diversity of governance bodies and } \\
\text { employees }\end{array}$ & $\begin{array}{c}\text { Number of Black people in } \\
\text { governance Bodies/Number of } \\
\text { employees in governance Bodies } \\
(405-1 \mathrm{~b})\end{array}$ & \\
\hline
\end{tabular}


The raw data obtained from the GRI reports of the selected banks and used in this study are shown in Table 4.

Table 4. Raw data for the selected banks.

\begin{tabular}{ccccc}
\hline & Banco do Brasil & Bradesco & Itaú & Santander \\
\hline 2016 Net Income (R million) & 8,304 & 17,121 & 23,263 & 7,339 \\
\hline 2017 Net Income (R\$ million) & 11,111 & 19,024 & 23,903 & 9,953 \\
\hline $\begin{array}{c}\text { Percentage of employees trained in } \\
\text { combating corruption (\%) }\end{array}$ & 45.3 & 100 & 93 & 8.5 \\
\hline $\begin{array}{c}\text { Energy consumption (MWh) } \\
\left.\text { Water consumption (m }{ }^{3}\right)\end{array}$ & 609,073 & 523,178 & 607,888 & $279,647.5$ \\
\hline Number of dismissals & $1,405,000$ & $1,597,760$ & $1,390,142$ & 627,678 \\
\hline Number of admissions & 1,587 & 16,120 & 9,454 & 5,400 \\
\hline $\begin{array}{c}\text { Percentage of women in governance } \\
\text { bodies (\%) }\end{array}$ & 287 & 5,766 & 14,145 & 5,454 \\
\hline $\begin{array}{c}\text { Percentage of Black people in } \\
\text { governance bodies (\%) }\end{array}$ & 4.84 & 5.15 & 12.71 & 22.22 \\
\hline $\begin{array}{c}\text { Number of employees } \\
\text { Number }\end{array}$ & 1.61 & 0.00 & 0.00 & 0.00 \\
\hline
\end{tabular}

\subsection{Application of the AHP method with the use of ratings}

The sustainability performance of the selected banks was compared using the AHP multicriteria method with ratings approach, as has already been mentioned. In this case, the evaluation criteria were based on the selected indicators (some values were divided by the number of employees of each institution in 2017, in order to allow for a comparison among these values), with banks being the alternatives to be compared.

The problem in question is summarized in Figure 1, in which the hierarchical structure related to AHP is represented.

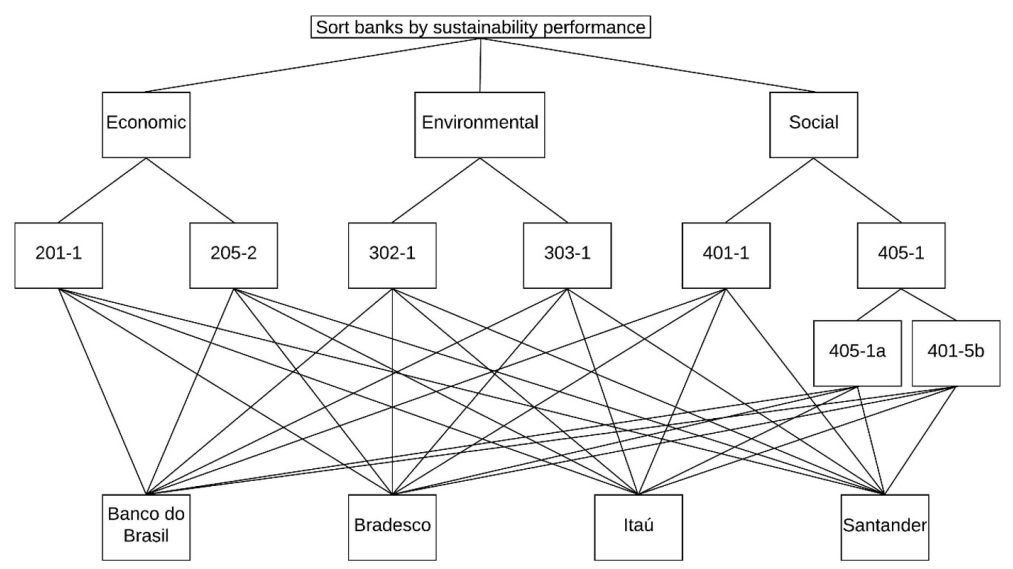

Figure 1. Hierarchical structure of the problem.

After the construction of the hierarchical structure of the problem, three specialists-a doctoral student and two doctors from the sustainability field-were asked to carry out the research in order to weigh the degree of importance of the criteria and sub-criteria used. In a meeting among specialists that make such assessments, the numerical scale of Saaty (Table 1) was presented, which allowed them to compare the factors of the hierarchy, 
while reaching a consensus. Next, the degree of importance of the criteria and sub-criteria in relation to the general objective of the hierarchical structure was determined. As the ratings approach was used, there was no need for comparisons among the alternatives.

Following the construction of the pair-by-pair comparison matrices, the Expert Choice (2004) software was used to perform the calculations. This program has several features and functions, such as graphical sensitivity analyses, which enable a broad understanding of the results obtained.

In addition, the consistency ratio was examined to enable specialists to verify the consistency of the evaluations. This ratio was calculated automatically by the aforementioned software. According to Saaty (1980), the consistency ratio should not exceed $10 \%$; this standard was adopted in the decision matrices elaborated in this work.

In order to determine the numerical values of the ratings, a comparison matrix of their degrees of intensity ( $A$ to $E$ ) was constructed, which allowed us to obtain the relative importance of the five levels.

The last stage of the research enabled the construction of a ranking of the banks analyzed in relation to the sustainability of each, based on the sum of the weights measured for each selection criterion. This phase included the analysis of the data obtained from the banks' sustainability reports using the aforementioned software. At this stage, a sensitivity analysis was also carried out regarding the weights used to assess the consistency of the results.

\section{Results}

Table 5 shows the data of the banks surveyed, which were obtained from their GRI sustainability reports for the year 2017. The objectives for each indicator are also shown (maximization or minimization). Regarding the data in which the objective was minimization, these were inverted ( $1 /$ data to be minimized), so that the objective became maximization, as is shown in Table 6.

Table 5. Data of the surveyed banks.

\begin{tabular}{|c|c|c|c|c|c|c|c|}
\hline \multirow{3}{*}{$\begin{array}{l}\text { Dimension } \\
\text { Indicators }\end{array}$} & \multicolumn{2}{|c|}{ Economic } & \multicolumn{2}{|c|}{ Environmental } & \multicolumn{3}{|c|}{ Social } \\
\hline & \multirow{2}{*}{$201-1$} & \multirow{2}{*}{$205-2$} & \multirow{2}{*}{ 302-1 (MWh) } & \multirow{2}{*}{$303-1\left(\mathrm{~m}^{3}\right)$} & \multirow[t]{2}{*}{$401-1$} & \multicolumn{2}{|l|}{$405-1$} \\
\hline & & & & & & $405-1 a$ & $405-1 b$ \\
\hline Objective & Max. & Max. & Min. & Min. & Min. & Max. & Max. \\
\hline Banco do Brasil & 1.3830 & 0.4530 & 6.1423 & 14.1689 & 5.5296 & 0.0484 & 0.0161 \\
\hline Bradesco & 1.1112 & 1.0000 & 5.2949 & 16.1704 & 2.7957 & 0.0515 & 0.0000 \\
\hline Itaú & 1.0275 & 0.9300 & 6.1198 & 13.9949 & 0.6684 & 0.1271 & 0.0000 \\
\hline Santander & 1.3562 & 0.0850 & 5.8992 & 13.2410 & 0.9901 & 0.2222 & 0.0000 \\
\hline
\end{tabular}

Table 6. Maximization data.

\begin{tabular}{|c|c|c|c|c|c|c|c|}
\hline \multirow{3}{*}{$\frac{\text { Dimension }}{\text { Indicators }}$} & \multicolumn{2}{|c|}{ Economic } & \multicolumn{2}{|c|}{ Environmental } & \multicolumn{3}{|c|}{ Social } \\
\hline & \multirow{2}{*}{ 201-1 } & \multirow[t]{2}{*}{$205-2$} & \multirow[t]{2}{*}{$302-1$ (inv.) } & \multirow[t]{2}{*}{ 303-1 (inv.) } & \multirow[t]{2}{*}{$401-1$ (inv.) } & \multicolumn{2}{|l|}{$405-1$} \\
\hline & & & & & & $405-1 a$ & $405-1 b$ \\
\hline Objective & Max. & Max. & Max. & Max. & Max. & Max. & Max. \\
\hline Banco do Brasil & 1.3830 & 0.4530 & 0.1628 & 0.0706 & 0.1808 & 0.0484 & 0.0161 \\
\hline Bradesco & 1.1112 & 1.0000 & 0.1889 & 0.0618 & 0.3577 & 0.0515 & 0.0000 \\
\hline Itaú & 1.0275 & 0.9300 & 0.1634 & 0.0715 & 1.4961 & 0.1271 & 0.0000 \\
\hline Santander & 1.3562 & 0.0850 & 0.1695 & 0.0755 & 1.0100 & 0.2222 & 0.0000 \\
\hline
\end{tabular}


In order to apply the ratings, the data for each column in Table 6 were idealized, that is, divided by the highest value obtained in the respective indicator (e.g., all data in the column referring to the indicator 201-1 were divided by 1.380), giving rise to Table 7 . The ratings were then applied to this dataset, as is shown in Table 8 . The qualification of each data point is shown in Table 9.

Table 7. Idealized maximization data.

\begin{tabular}{|c|c|c|c|c|c|c|c|}
\hline \multirow{2}{*}{$\begin{array}{l}\text { Dimension } \\
\text { Indicators }\end{array}$} & \multicolumn{2}{|c|}{ Economic } & \multicolumn{2}{|c|}{ Environmental } & \multicolumn{3}{|c|}{ Social } \\
\hline & $201-1$ & 205-2 & 302-1 (inv.) & 303-1 (inv.) & 401-1 (inv.) & $405-1$ & \\
\hline & & & & & & $405-1 a$ & $405-1 b$ \\
\hline Objective & Max. & Max. & Max. & Max. & Max. & Max. & Max. \\
\hline Banco do Brasil & 1,0000 & 0,4530 & 0,8620 & 0,9345 & 0,1209 & 0,2178 & 1,0000 \\
\hline Bradesco & 0,8035 & 1,0000 & 1,0000 & 0,8188 & 0,2391 & 0,2318 & 0,0000 \\
\hline Itaú & 0,7430 & 0,9300 & 0,8652 & 0,9461 & 1,0000 & 0,5720 & 0,0000 \\
\hline Santander & 0,9806 & 0,0850 & 0,8976 & 1,0000 & 0,6751 & 1,0000 & 0,0000 \\
\hline
\end{tabular}

Table 8. Ratings

\begin{tabular}{cc}
\hline Ratings & Interval \\
\hline A & 0.8001 to 1.0000 \\
\hline B & 0.6001 to 0.8000 \\
\hline C & 0.4001 to 0.6000 \\
\hline D & 0.2001 to 0.4000 \\
\hline E & 0.0000 to 0.2000
\end{tabular}

Table 9. Ratings applied to the dataset.

\begin{tabular}{|c|c|c|c|c|c|c|c|}
\hline \multirow{3}{*}{$\begin{array}{l}\text { Dimension } \\
\text { Indicators }\end{array}$} & \multicolumn{2}{|c|}{ Economic } & \multicolumn{2}{|c|}{ Environmental } & \multicolumn{3}{|c|}{ Social } \\
\hline & \multirow[t]{2}{*}{$201-1$} & \multirow[t]{2}{*}{$205-2$} & \multirow[t]{2}{*}{ 302-1 (inv.) } & \multirow[t]{2}{*}{ 303-1 (inv.) } & \multirow[t]{2}{*}{$401-1$ (inv.) } & \multicolumn{2}{|l|}{$405-1$} \\
\hline & & & & & & $405-1 a$ & 405-1b \\
\hline Banco do Brasil & $A$ & $\mathrm{C}$ & $A$ & $A$ & $E$ & $\mathrm{D}$ & $A$ \\
\hline Bradesco & A & A & $A$ & A & $\mathrm{D}$ & $\mathrm{D}$ & $E$ \\
\hline Itaú & $\mathrm{B}$ & $A$ & $A$ & $A$ & $A$ & $\mathrm{C}$ & $E$ \\
\hline Santander & A & $E$ & A & A & B & A & $E$ \\
\hline
\end{tabular}

\subsection{Results of applying the AHP method with the use of ratings}

In this section, the AHP method with the ratings approach was applied with the use of relevant mathematical equations.

We chose to assign the same weight to the second level criteria (economic, environmental, and social), based on the principles of the triple bottom line, in which all dimensions are equally important for sustainable performance (Elkington, 1997). Tables 10-13 show the sub-criteria comparisons established by the experts; it should be noted that the consistency index should always be less than 10\% (Saaty, 1980). 
Table 10. Comparison matrix of the economic criterion sub-criteria.

\begin{tabular}{ccc} 
& $\mathbf{2 0 1 - 1}$ & $\mathbf{2 0 5 - 2}$ \\
\hline $\mathbf{2 0 1 - 1}$ & 1 & 3 \\
\hline $\mathbf{2 0 5 - 2}$ & $1 / 3$ & 1 \\
\hline & Consistency Ratio $=0.00$ & \\
\hline
\end{tabular}

Table 11. Comparison matrix of the environmental criterion sub-criteria.

\begin{tabular}{ccc}
\hline & $302-1$ & $303-1$ \\
\hline $302-1$ & 1 & 7 \\
\hline $303-1$ & $1 / 7$ & 1 \\
\hline & Consistency Ratio $=0.00$ \\
\hline
\end{tabular}

Table 12. Comparison matrix of the social criterion sub-criteria.

\begin{tabular}{ccc} 
& $\mathbf{4 0 1 - 1}$ & $\mathbf{4 0 5 - 1}$ \\
\hline $\mathbf{4 0 1 - 1}$ & 1 & 6 \\
\hline $\mathbf{4 0 5 - 1}$ & $1 / 6$ & 1 \\
\hline & Consistency Ratio $=0.00$ \\
\hline
\end{tabular}

Table 13. Comparison matrix of the $405-1$ sub-criterion sub-sub-criteria.

\begin{tabular}{ccc} 
& 405-1a & 405-1b \\
\hline $\mathbf{4 0 5 - 1 a}$ & 1 & 1 \\
\hline $\mathbf{4 0 5 - 1 b}$ & 1 & 1 \\
\hline & Consistency Ratio $=0.00$ & \\
\hline
\end{tabular}

After the experts' comparisons for each criterion and sub-criterion, the rating values were determined using the matrix shown in Table 14.

Table 14. Ratings comparison matrix.

\begin{tabular}{cccccc}
\hline & A & B & C & D & E \\
\hline A & 1 & 3 & 5 & 7 & 9 \\
\hline B & $1 / 3$ & 1 & 3 & 5 & 7 \\
\hline C & $1 / 5$ & $1 / 3$ & 1 & 3 & 5 \\
\hline $\mathbf{D}$ & $1 / 7$ & $1 / 5$ & $1 / 3$ & 1 & 3 \\
\hline $\mathbf{E}$ & $1 / 9$ & $1 / 7$ & $1 / 5$ & $1 / 3$ & 1 \\
\hline & Consistency Ratio $=0.05$ (less than 0.10$)$ & & \\
\hline
\end{tabular}

The values corresponding to each rating, which were normalized, are shown in Table 15.

Table 15. Rating values.

\begin{tabular}{cc}
\hline Rating & Assigned value \\
\hline A & 0.513 \\
B & 0.261 \\
\hline C & 0.129 \\
\hline D & 0.063 \\
\hline E & 0.033 \\
\hline
\end{tabular}


Figure 2 presents a summary of the results obtained after the data were fed into the Expert Choice software (2004). The data shown have already been normalized.

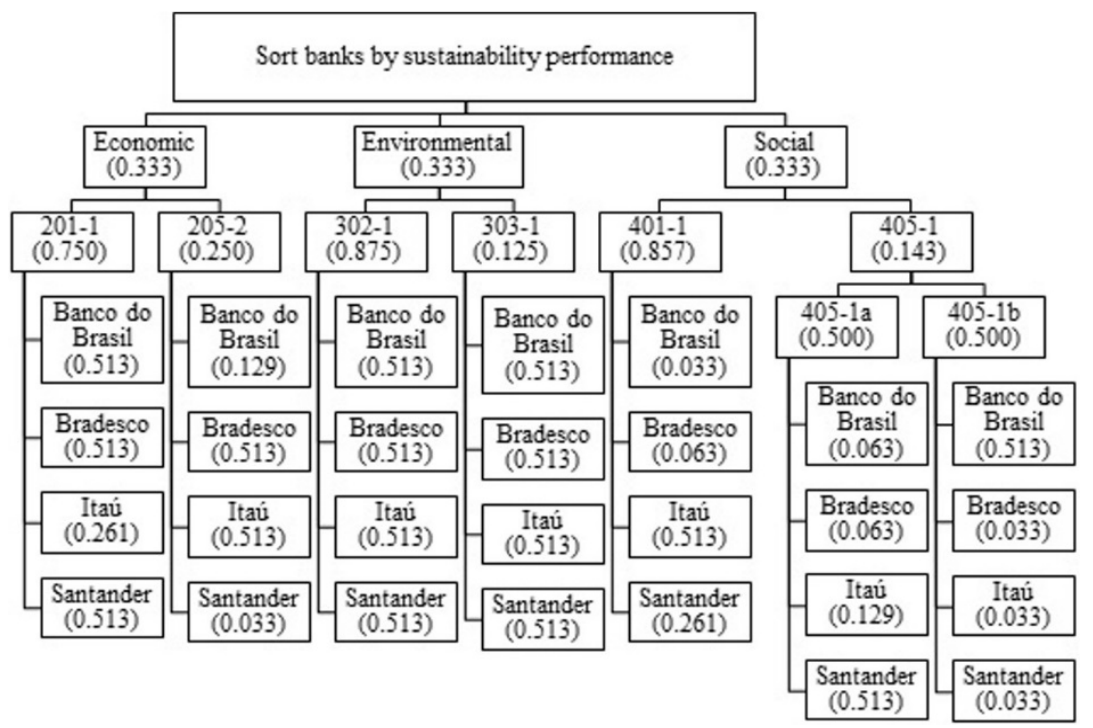

Figure 2. Weights for the criteria, sub-criteria, and ratings of the alternatives

Table 16 shows the general sustainability ranking for the banks analyzed after the Expert Choice (2004) calculations.

Table 16. Sustainability ranking.

\begin{tabular}{ccc}
\hline Position & Institution & Score \\
\hline 1 & Itaú & 0.329 \\
\hline 2 & Santander & 0.260 \\
\hline 3 & Bradesco & 0.214 \\
\hline 4 & Banco do Brasil & 0.196 \\
\hline
\end{tabular}

The last step consisted of a sensitivity analysis for each criterion (economic, environmental, and social). With the aid of Expert Choice (2004), gradient graphs were drawn, as is shown in Figures 3, 4, and 5.

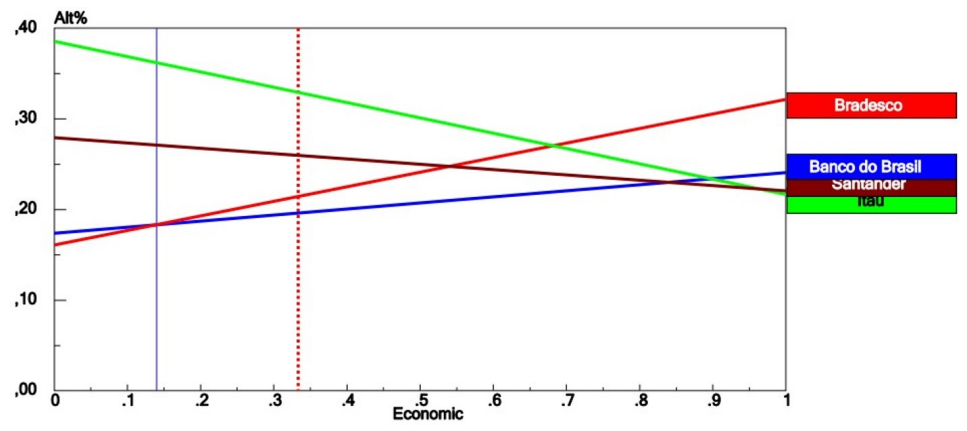

Figure 3. Sensitivity analysis for the economic criterion. 
In the case of the economic criterion, the first change in the positions occurred with a weight reduction from 0.33 to approximately 0.15 (55\% variation).

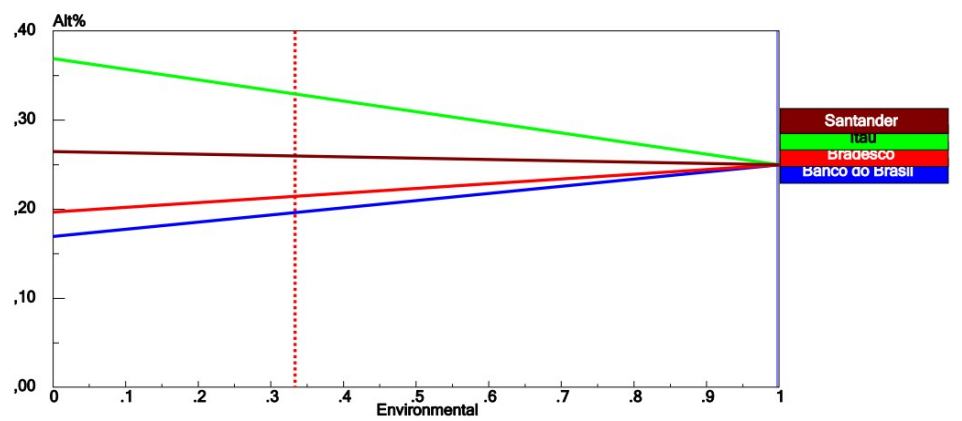

Figure 4. Sensitivity analysis for the environmental criterion.

With regard to the environmental criterion, no weight changes would lead to a change in the rank of the banks studied.

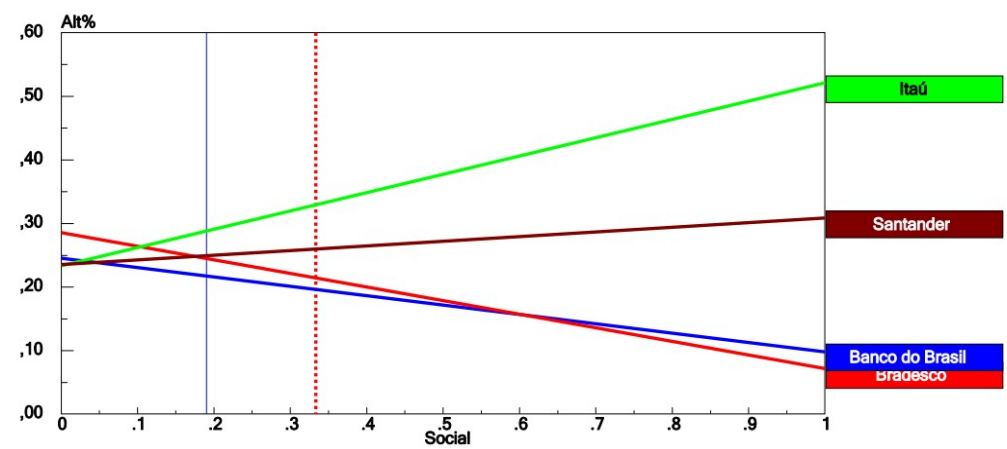

Figure 5. Sensitivity analysis for the social criterion.

Regarding the social criterion, the positions would change with the minimum weight reduction from 0.33 to approximately 0.18 (45\% variation).

\section{DISCUSSION}

In this study we used data from the GRI reports of four banks operating in Brazil, in order to compare the contribution of each to sustainable development. As reported by other authors who also analyzed GRI reports from banking institutions (Almeida et al., 2017; Silva et al., 2019), it was not possible to compare all GRI indicators, either owing to their absence in the reports, or owing to the very divergent disclosures of the different banks examined. As a result, some relevant aspects, such as paper consumption and waste generation were left out of this study. The lack of standardization in the GRI guidelines makes it difficult to compare the reports of different companies, as pointed out by several authors, in studies carried out in different economic sectors (Danoucaras et al., 2014; Scholl et al., 2015; Spuerk et al., 2017).

Regarding the economic criterion, the data obtained from the sustainability reports of the banks selected in this study show slightly different values for the 201-1 sub-criterion 
(direct economic value generated and distributed), with only Banco Itaú obtaining a B rating. However, in relation to the 205-2 sub-criterion (communication and training about anti-corruption policies and procedures), it was evident through the Banco do Brasil and Santander analysis that training in anti-corruption practices still needs to become a higher priority for these banks, which were given $\mathrm{C}$ and $\mathrm{E}$ ratings, respectively.

The smallest discrepancy among the banks was obtained in relation to the environmental criterion. All of them were rated A for the sub-criteria 302-1 (energy consumption within the organization) and 303-1 (water withdrawal by source), which shows that energy and water consumption are treated similarly by the researched institutions, thereby emphasizing that the adequate management of these natural resources directly reflects on the companies' profit.

However, it was the social criterion that stood out in the most negative manner. None of the banks obtained the same rating in relation to the 401-1 sub-criterion (new employee hires and employee turnover), with Banco Itaú having the best rating among the banks surveyed. On the other hand, Banco do Brasil, which was assigned an $\mathrm{E}$ rating, had the worst value, which shows that the replacement of dismissed employees has not been occurring substantially in this bank.

Within sub-criterion 405-1 (diversity of governance bodies and employees), the low absolute values obtained for sub-criteria 405-1a (number of women in governance bodies/number of employees in governance bodies) and 405-1b (number of Black people in governance bodies/number of employees in governance bodies) show that diversity in governance bodies is far from being a priority for banks, with women and Black people not occupying such positions to any considerable extent. In none of the banks examined did women occupy more than $25 \%$ of the positions in governance sectors and only Banco do Brasil employed Black people in such positions, however the latter still accounted for less than $2 \%$ of the total. Such numbers clearly do not represent Brazilian diversity.

The social indicators presented show that, much like the European banks analyzed by Avrampou et al. (2019), the financial institutions operating in Brazil still have a long way to go in order to contribute more effectively to the achievement of the objectives of Agenda 2030 (UN, 2015), especially in terms of issues related to equal opportunities.

The application of the AHP method with the use of ratings allowed us to address the final objective of the problem, which was to rank the banks according to their sustainability performance. In addition, this method allowed for other observations regarding the priorities of each criterion and sub-criterion.

Based on the experts' judgment, the 201-1 criterion was considered the most relevant for the economic dimension (this had a value of 0.750 as opposed to the 0.250 value of the 205-2 sub-criterion). Sub-criterion 302-1 (0.875) was considered more relevant than sub-criterion 303-1 in terms of the environmental dimension, as water consumption in banking institutions is less of a concern compared to energy consumption. In the social criterion, the 401-1 (0.857) sub-criterion was considered more relevant than the 405-1 (0.143) sub-criterion. Within the last sub-criterion mentioned, 405-1a was considered as important as $405-1 \mathrm{~b}$. It should be noted that the subjectivity of the specialists affected directly the final result of the analysis, which corroborates the results of Aharonovitz \& Vieira (2014).

The ranking obtained with the use of ratings for the alternatives (banks) was as follows: Itaú in the first place (0.328), followed by Santander (0.252), Bradesco (0.214), and Banco do Brasil (0.205) in the last place.

The use of ratings proved to be efficient, as it helped reduce the subjective nature of the assessments and was based on absolute data; additionally, it helped decrease the number of assessments made by decision makers in relation to the traditional AHP 
method. Another advantage is that adding institutions to the problem would not require new decisions by specialists. The sensitivity analysis proved the consistency of the results, as, any ranking changes would require the weight of the criteria to vary by at least $45 \%$ (in the case of the social criterion).

Rebelato et al. (2015) also compared banks' GRI reports using the AHP, considering only environmental indicators. After analyzing reports from 2009 to 2012, they obtained the following ranking: Bradesco, Itaú, Bank of Brazil, Santander, and Caixa Econômica Federal. It should be noted that, in this paper, Caixa Econômica Federal was left out, as it is not part of the ISE 2018 portfolio (B3, 2021). The other banks were analyzed in this research and were all assigned $A$ ratings in terms of their environmental performance. Considering the three dimensions of the sustainability tripod, it is evident that the ranking obtained in this study was quite different from the rankings that were obtained from the aforementioned study. Some of the possible reasons for this divergence could be attributed to certain differences between the two studies. For example, the reports analyzed in the two studies were from different years [2009-2012 in Rebelato et al. (2015); 2017 in the present study] and not all of the indicators were the same in both studies. Additionally, in the present study the three dimensions of sustainability were analyzed, while only the environmental one was considered in Rebelato et al. (2015), and the weights of the indicators were assigned by different judges, none of whom participated in both surveys.

\section{CONCLUSION}

The aim of this study was to compare the socioeconomic and environmental sustainability of four banks that operate in the Brazilian market by analyzing the indicators described in their GRI reports for 2017.

The sustainability performance assessment was carried out based on the indicators proposed by the GRI ("GRI Standards" version). Six indicators, which were published in a common manner in all the analyzed reports and tackled the economic, environmental, and social dimensions, were selected. The data used in the survey were collected from sustainability reports published by each bank.

These indicators were weighed by experts, who considered their relevance in terms of the sustainability of the banking institutions. The method used for this weighing was AHP, which is one of the best known and most used tools to support multicriteria decisionmaking. The ratings approach was used to compare the relative performance of the banks. Through the AHP method, the problem was structured and divided into criteria, subcriteria, and alternatives, which allowed the construction of a sustainability performance ranking for the analyzed banks.

The application of the AHP with the use of ratings resulted in the following ranking: Itaú in the first place, followed by Santander, Bradesco, and Banco do Brasil in the last place. Through the data presented in this paper it is evident that there is room for progress in relation to sustainability, especially in terms of the social dimension, in the banking sector. The numbers expressed in the indicator "diversity in governance bodies and employees" show that Black people and women are minorities in high-ranking positions; additionally, in some of these institutions, there are no Black people in high-ranking positions, which reflects the inequalities of the Brazilian society.

The AHP method with the use of ratings proved to be efficient, especially because it allowed for the weighing of criteria and sub-criteria, thus being a useful tool for comparing the sustainability of banks through the classification of available alternatives. This method 
also allowed us to demonstrate the fluctuations of the results in terms of variations in the weighings, depending on the degree of importance given to each criterion and subcriterion, through sensitivity analysis. In addition, the use of the Expert Choice software enabled the quick treatment of the problem, by leading to objective and clear results.

One of the limitations of this study was the absence of some common indicators in the analyzed reports (or data presented in a very divergent way, without a standard); this made it impossible to compare the banks in terms of these indicators. This limitation could be mitigated if the GRI reports had stricter disclosure standards. Additionally, it is worth mentioning that although the AHP method is subjective, the knowledge of the decision makers on the issues addressed was fundamental in determining the quality of the results.

Future studies could focus on the use of other MDS methods in order to compare the sustainability performance of the analyzed banks. Another future research direction could be toward the application of the method proposed herein for subsequent years, as this would facilitate the tracing of the evolution of the sustainability issue in banking institutions in Brazil.

\section{References}

Aharonovitz, M., \& Vieira, J. (2014). Proposta de modelo multicritério para seleção de fornecedores de serviços logísticos. Revista Gestão da Produção, Operações e Sistemas, 9(1), 9-26. http://dx.doi.org/10.15675/gepros.v0i1.1148.

Almeida, H. J. L., Nascimento, E. R., Jr. \& Costa, A. J. B. (2017). Práticas de sustentabilidade corporativa no Brasil: análise das instituições financeiras integrantes do Índice de Sustentabilidade Empresarial. Revista Gestão e Desenvolvimento, 14(1), 84-99. http://dx.doi.org/10.25112/rgd.v14i1.898.

Amaral, M. C., Zonatti, W. F., Silva, K. L., Karam, D. Jr., Amato, J., No. \& Baruque-Ramos, J. (2018). Industrial textile recycling and reuse in Brazil: case study and considerations concerning the circular economy. Gestão \& Produção, 25(3), 431-443. http://dx.doi.org/10.1590/0104-530x3305.

Avrampou, A., Skouloudis, A., Iliopoulos, G., \& Khan, N. (2019). Advancing the Sustainable Development Goals: evidence from leading European banks. Sustainable Development, 27(4), 743-757. http://dx.doi.org/10.1002/sd.1938.

B3. Brasil, Bolsa, Balcão. (2021). Índice de Sustentabilidade Empresarial (ISE). Retrieved on July 05, 2021, from http://www.b3.com.br/pt_br/market-data-e-indices/indices/indices-desustentabilidade/indice-de-sustentabilidade-empresarial-ise.htm

Bana e Costa, C. A., \& Vansnick, J. C. (1995). Uma nova abordagem ao problema da construção de uma função de valor cardinal: MACBETH. Investigação Operacional, 15, 15-35.

Banco Central do Brasil - BCB. (2014, 28 de abril). Resolução no 4.327, de 25 de abril de 2014. Dispõe sobre as diretrizes que devem ser observadas no estabelecimento e na implementação da Política de Responsabilidade Socioambiental pelas instituições financeiras e demais instituições autorizadas a funcionar pelo Banco Central do Brasil (seção 1, n 79, p. 22). Brasília, DF: Diário Oficial da República Federativa do Brasil.

Banco Central do Brasil - BCB. (2020). Quantitativo de municípios com atendimento bancário no País. Retrieved on May 16, 2020, from

https://www.bcb.gov.br/content/estabilidadefinanceira/evolucaosfnmes/201812Quadro\%2007\%20-

\%20Quantitativo\%20de\%20munic\%C3\%ADpios\%20com\%20atendimento\%20banc\%C3\%A1ri ०\%20no\%20Pa\%C3\%ADs.pdf

Borgert, T., Donovan, J. D., Topple, C., \& Masli, E. K. (2018). Initiating sustainability assessments: insights from practice on a procedural perspective. Environmental Impact Assessment Review, 72, 99-107. http://dx.doi.org/10.1016/j.eiar.2018.05.012. 
Borges, M. L., Anholon, R., Cooper Ordoñez, R. E., Quelhas, O. L. G., Santa-Eulalia, L., \& Leal Filho, W. (2018). Corporate Social Responsibility (CSR) practices developed by Brazilian companies: an exploratory study. International Journal of Sustainable Development and World Ecology, 25(6), 509-517. http://dx.doi.org/10.1080/13504509.2017.1416700.

Brans, J. P., Vincke, Ph., \& Mareschal, B. (1986). How to select and how to rank projects: The Promethee method. European Journal of Operational Research, 24(2), 228-238. http://dx.doi.org/10.1016/0377-2217(86)90044-5.

Brooks, C., \& Oikonomou, I. (2018). The effects of environmental, social and governance disclosures and performance on firm value: A review of the literature in accounting and finance. The British Accounting Review, 50(1), 1-15. http://dx.doi.org/10.1016/j.bar.2017.11.005.

Campos, L. M. S., Sehnem, S., Oliveira, M. A. S., Rossetto, A. M., Coelho, A. L. A. L., \& Dalfovo, M. S. (2013). Relatório de sustentabilidade: perfil das organizações brasileiras e estrangeiras segundo o padrão da Global Reporting Initiative. Gestão \& Produção, 20(4), 913-926. http://dx.doi.org/10.1590/S0104-530X2013005000013.

Choice, E. (2004). Expert Choice Resource Aligner (Version 11) [Computer software]. Arlington: Expert Choice, Inc.

Danoucaras, A. N., Woodley, A. P., \& Moran, C. J. (2014). The robustness of mine water accounting over a range of operating contexts and commodities. Journal of Cleaner Production, 84, 727-735. http://dx.doi.org/10.1016/j.jclepro.2014.07.078.

Departamento Intersíndical de Estatísticas e Estudos Socioeconômicos - DIEESE. (2019). Desempenho dos Bancos em 2018. Retrieved on May 16, 2020, from https://www.dieese.org.br/desempenhodosbancos/2019/desempenhoDosBancos2018/index.h tml?page $=1$

Di Agustini, C. A., \& Giannetti, B. F. (2018). Assessment of environmental sustainability indexes of water supply and sewage treatment companies listed on the BM\&FBOVESPA. Gestão \& Produção, 25(4), 792-806. http://dx.doi.org/10.1590/0104-530x3459-17.

Elkington, J. (1997). Cannibals with Forks: The Triple Bottom Line of 21st Century Business (1a ed.). Oxford: Capstone.

Etzion, D., Gehman, J., Ferraro, F., \& Avidan, M. (2017). Unleashing sustainability transformations through robust action. Journal of Cleaner Production, 140, 167-178. http://dx.doi.org/10.1016/j.jclepro.2015.06.064.

Federação Brasileira de Bancos - FEBRABAN. (2020). Programa FEBRABAN de Valorização da Diversidade. Retrieved on May 16, 2020, from https://portal.febraban.org.br/pagina/3100/86/pt-br/censo-diversidade

Ferreira-Quilice, T., \& Caldana, A. C. F. (2015). Aspectos negativos no modelo de reporte proposto pela GRI: a opinião das organizações que reportam. Revista ADM, 50(4), 405-415. http://dx.doi.org/10.5700/rausp1209.

Fuente, J. A., García-Sánchez, I. M., \& Lozano, M. B. (2017). The role of the board of directors in the adoption of GRI guidelines for the disclosure of CSR information. Journal of Cleaner Production, 141, 737-750. http://dx.doi.org/10.1016/j.jclepro.2016.09.155.

Gil, A. C. (2017). Como elaborar projetos de pesquisa (6a ed.). São Paulo: Atlas.

Global Reporting Iniative - GRI. (2018). G4 to Standards: transition complete. Retrieved on May 16, 2020, from https://www.globalreporting.org/information/news-and-press-center/Pages/G4to-Standards-transition-complete.aspx

Global Reporting Iniative - GRI. (2020a). GRI's History. Retrieved on May 16, 2020, from https://www.globalreporting.org/information/about-gri/gri-history/Pages/GRI's\%20history.aspx

Global Reporting Iniative - GRI. (2020b). Sustainability Disclosure Database. Retrieved on May 16, 2020, from http://database.globalreporting.org 
Gomes, L. F. A. M., \& Lima, M. M. P. P. (1992a). From modeling individual preferences to multicriteria ranking of discrete alternatives: a look at prospect theory and the additive difference model. Foundations of Computing and Decision Sciences, 17(3), 171-184.

Gomes, L. F. A. M., \& Lima, M. M. P. P. (1992b). TODIM: Basics and Application to Multicriteria Ranking of Projects with Environmental Impacts. Foundations of Computing And Decision Sciences, 16(4), 113-127.

Gomes, L. F. A. M., \& Rangel, L. A. D. (2009a). Determining the utility functions of criteria used in the evaluation of real estate. International Journal of Production Economics, 117(2), 420-426. http://dx.doi.org/10.1016/j.ijpe.2008.12.006.

Gomes, L. F. A. M., \& Rangel, L. A. D. (2009b). An application of the TODIM method to the multicriteria rental evaluation of residential properties. European Journal of Operational Research, 193(1), 204-211. http://dx.doi.org/10.1016/j.ejor.2007.10.046.

Gomes, L. F. A. M., Araya, M. C. G., \& Carignano, C. (2004). Tomada de decisões em cenários complexos: Introdução aos métodos discretos do apoio multicritério à decisão (1a ed.). São Paulo: Cengage Learning.

Jugend, D., \& Figueiredo, J. (2017). Integrating environmental sustainability and project portfolio management: case study in an energy firm. Gestão \& Produção, 24(3), 526-537. http://dx.doi.org/10.1590/0104-530x3451-16.

Keeney, R. L., \& Raiffa, H. (1976). Decision with Multiple Objectives: Preferences and Value Trade-offs (1a ed.). New York: John Wiley \& Sons.

Liubachyna, A., Secco, L., \& Pettenella, D. (2017). Reporting practices of State Forest Enterprises in Europe. Forest Policy and Economics, 78, 162-172. http://dx.doi.org/10.1016/j.forpol.2017.01.019.

Masud, M., Hossain, M., \& Kim, J. (2018). Is green regulation effective or a failure: comparative analysis between Bangladesh Bank (BB) green guidelines and global reporting initiative guidelines. Sustainability, 10(4), 1267-1286. http://dx.doi.org/10.3390/su10041267.

Mello, L. C. B. B., Bandeira, R. A. M., \& Brandalise, N. (2017). Selection of rework measurement methodology utilizing AHP method. Gestão \& Produção, 25(1), 94-106. http://dx.doi.org/10.1590/0104-530x2732-16.

Mello, M. F., \& Mello, A. Z. (2017). An analysis of the practices of social responsibility and sustainability as strategies for industrial companies in the furniture sector: a case study. Gestão \& Produção, 25(1), 81-93. http://dx.doi.org/10.1590/0104-530x1625-16.

Olher, C. C., Melo, M. F. S., Souza, R., \& Campos-Silva, W. L. (2018). Estratégia de responsabilidade social corporativa no setor bancário: análise da atuação socioambiental do Bradesco e Itaú Unibanco. Revista Metropolitana de Sustentabilidade, 8(1), 116-131.

Paoli, D., \& Moraes, L. A. F. (2011). Apoio multicritério à decisão como subsídio à gestão ambiental: o caso da Aggreko Brasil. Gestão \& Produção, 18(2), 379-390. http://dx.doi.org/10.1590/S0104-530X2011000200012.

Petrillo, A., Carotenuto, P., Baffo, I., \& De Felice, F. (2018). A web-based multiple criteria decision support system for evaluation analysis of carpooling. Environment, Development and Sustainability, 20(5), 2321-2341. http://dx.doi.org/10.1007/s10668-017-9991-z.

Rahman, M., Islam, R., Wan Husain, W. R., \& Ahmad, K. (2019). Developing a hierarchical model to enhance business excellence in hotel industry of Bangladesh. International Journal of Contemporary Hospitality Management, 31(4), 1836-1856. http://dx.doi.org/10.1108/IJCHM02-2018-0110.

Rebelato, M. G., de Almeida, A. Z., \& Rodrigues, A. M. (2015). Desempenho ambiental de instituições financeiras: um estudo comparativo entre os cinco principais bancos brasileiros. Revista Gestão Industrial, 11(1). http://dx.doi.org/10.3895/gi.v11n1.1859.

Ribeiro, M. C. C. R., \& Alves, A. S. (2017). The problem of research project portfolio selection in educational organizations: a case study. Gestão \& Produção, 24(1), 25-39. http://dx.doi.org/10.1590/0104-530x2089-16. 
Rosa, C. R. M., Steiner, M. T. A., \& Colmenero, J. C. (2015). Utilização de processo de análise hierárquica para definição estrutural e operacional de centros de distribuição: uma aplicação a uma empresa do ramo alimentício. Gestão \& Produção, 22(4), 935-950. http://dx.doi.org/10.1590/0104-530X986-13.

Roy, B. (1968). Classement et choix en presence de points de vue multiples (la methode ELECTRE). Revue Française D'informatique et de Recherche Opérationnelle, 2(1), 57-75.

Ryszawska, B., \& Zabawa, J. (2018). The Environmental Responsibility of the World's Largest Banks. Economics and Business, 32(1), 51-64. http://dx.doi.org/10.2478/eb-2018-0004.

Saaty, T. L. (1980). The Analytic Hierarchy Process (1a ed.). New York: Mcgraw-Hill.

Saaty, T. L. (2006). Rank from comparisons and from ratings in the analytic hierarchy/network processes. European Journal of Operational Research, 168(2), 557-570. http://dx.doi.org/10.1016/j.ejor.2004.04.032.

Saaty, T. L. (2008). Decision making with the analytic hierarchy process. International Journal of Services Sciences, 1(1), 83-98. http://dx.doi.org/10.1504/IJSSCI.2008.017590.

Santos, F. F., Queiroz, R. C. S., \& Almeida Neto, J. A. (2017). Evaluation of the application of Cleaner Production techniques in a dairy industry in Southern Bahia. Gestão \& Produção, 25(1), 117-131. http://dx.doi.org/10.1590/0104-530x2234-16.

Scholl, C. A., Hourneaux, F. Jr, \& Galleli, B. (2015). Sustentabilidade organizacional: aplicação de índice composto em uma empresa do setor químico. Gestão \& Produção, 22(4), 695-710. http://dx.doi.org/10.1590/0104-530X1343-13.

Sellitto, M. A., \& Hermann, F. F. (2016). Prioritization of green practices in GSCM: case study with companies of the peach industry. Gestão \& Produção, 23(4), 871-886. http://dx.doi.org/10.1590/0104-530x2516-15.

Siew, R. Y. J. (2015). A review of corporate sustainability reporting tools (SRTs). Journal of Environmental Management, 164, 180-195. http://dx.doi.org/10.1016/j.jenvman.2015.09.010. PMid:26379255.

Silva, R. C., Santos, F. de A., \& dos Santos, N. M. B. F. (2019). A atuação do Relato Integrado nas empresas brasileiras: um estudo comparativo sobre a forma de divulgação do RI entre os dois maiores bancos privados nacionais. Revista Metropolitana de Sustentabilidade, 9(2), 86-101.

Spuerk, S., Drobe, M., \& Lottermoser, B. G. (2017). Evaluating resource efficiency at major copper mines. Minerals Engineering, 107, 27-33. http://dx.doi.org/10.1016/j.mineng.2016.12.005.

Sucena, E., \& Marinho, M. M. de O. (2019). Environmental disclosure analysis of sustainability reports the Brazilian and international brewing industry based on Global Reporting Initiative GRI. Gestão \& Produção, 26(3), e3120. http://dx.doi.org/10.1590/0104-530x3120.

United Nations - UN. (2015). Transformando Nosso Mundo: A Agenda 2030 para o Desenvolvimento Sustentável. Retrieved on May 16, 2020, from https://nacoesunidas.org/pos2015/agenda2030/

World Commission on Environment and Development - WCED. (1987). Our Common Future. Oxford: Oxford University Press. 